\title{
Análise de mudanças no canal fluvial do Rio Paraná a jusante da Usina de Porto Primavera - SP
}

\author{
Kátia Mara de JESUS
}

Dissertação de Mestrado: Curso de Mestrado em Geografia - UFPR

Data da defesa: 16 abr. 2003

Banca:

\author{
Everton Passos (orientador) \\ Leonardo José Cordeiro Santos \\ Hélio Olympio da Rocha
}

\section{RESUMO}

A partir da década de 70, a Geomorfologia Fluvial adotou uma perspectiva de análise temporal para os estudos das mudanças fluviais e tem-se preocupado com as modificações decorrentes da maior atuação do homem sobre o ambiente fluvial sendo que estas modificações podem ser consideradas diretas e indiretas. Dentre as ações antrópicas mais impactantes destacam-se as obras de engenharia. Nesse contexto se sobressaem as usinas hidrelétricas, que de certo modo alteram a dinâmica da "Bacia Hidrográfica". Como resultado desse processo de ocupação da bacia são identificadas 3 áreas de influência (setores) da barragem, ou seja a montante dela, junto à barragem propriamente dita e a jusante desta. Neste sentido, o presente trabalho delimitouse à terceira área jusante, com os objetivos de realizar um acompanhamento histórico das mudanças (erosão e sedimentação) no rio Paraná, na região de Porto Primavera-SP, a partir da análise da variabilidade (disposição e dimensão) do segmento do canal fluvial, identificando neste setor os impactos gerados pela barragem de Porto Primavera, assim como verificar nas áreas de seu entorno as condições de preservação. Cabe ressaltar que a presente dissertação tem um caráter exploratório na identificação e registro dos fatores condicionantes das mudanças, sendo que estes foram observados e registrados a partir de documentos cartográficos existentes e de imagens orbitais, apoiados em levantamentos de campo e dados disponíveis. A análise foi centrada no que se refere à variabilidade da disposição e dimensão do segmento do canal fluvial, e uso da terra em seu entorno, delimitando-se nesse estudo de caso à margem esquerda do rio Paraná. Dentre os procedimentos adotados, foram utilizados recursos do Geoprocessamento que possibilitaram a elaboração de planos de informações qualitativos e quantitativos, base da presente análise, bem como a geração de mapas e cartogramas. A partir dos resultados alcançados foi possível verificar que ocorreram mudanças significativas no canal propriamente dito, assim como nas margens. Constatouse que nas margens das ilhas o processo mais atuante foi o de erosão, já nas margens o canal fluvial apresentou um percentual maior de assoreamento no segmento em análise. Quanto ao uso da terra em seu entorno, no que se refere à aplicabilidade da Legislação Ambiental, constatou-se que este uso vem contribuindo ao longo dos anos para o aumento das áreas de conflitos, entre ocupação e preservação. Este estudo permitiu apontar a necessidade de uma reordenação espacial do uso da terra no seu entorno, bem como apontar a demanda de estudos com vistas à aplicação de técnicas de controle ao processo erosivo, dadas as suas implicações na área em estudo.

\section{Palavras-chave:}

Geomorfologia fluvial, rio Paraná, mudanças no canal fluvial. 